\title{
PERANCANGAN MESIN POTONG AKRILIK YANG ERGONOMIS DAN EKONOMIS MENGGUNAKAN METODE ERGONOMIC FUNCTION DEPLOYMENT (EFD)
}

\author{
Huda Anshori \\ Program Studi Teknik Industri, Fakultas Teknik, Universitas Muhammadiyah Riau \\ Jalan Tuanku Tambusai Ujung, Kecamatan Tampan, Kelurahan Delima, Kota Pekanbaru, Riau \\ 28291 \\ E-mail: hudaanshori74@gmail.com
}

\begin{abstract}
Advertising services which include the process of creating, producing and distributing advertisements, one example of which is billboards used to help entrepreneurs in promoting goods and services sold in Pekanbaru. In the process of working on advertising media, especially in the cutting process using cutting tools in the form of circular saws and scroll saws. In the cutting process there are several obstacles that are often experienced by operators, cutting edges are difficult to find, the unit is expensive, cutting edges often break, dynamo power can drop dramatically, work takes a long time and operators feel tired, that's why it is necessary to design an acrylic cutting machine which can be used to meet the operators needs at work. The design method uses the Ergonomic Function Deployment (EFD) method. This method is a development of the Quality Function Deployment $(Q F D)$ method. The stages in this research are introduction, identification, formulation, goal setting, method application followed by analysis and discussion, and finally conclusions, suggestions, and improvements. Based on the research, the variable results obtained from a closed questionnaire and processed using SPSS 16 software.
\end{abstract}

Keywords : Acrylic Cutting Tool, Design, Ergonomic Function Deployment

\begin{abstract}
Abstrak
Berkembangnya jasa periklanan yang meliputi proses kreasi, produksi dan distribusi dari iklan yang dihasilkan salah satu contohnya billboard memudahkan para pengusaha di Kota Pekanbaru dalam mempromosikan barang atau jasa yang mereka jual. Dalam proses pengerjaan media iklan itu sendiri terkhusus pada proses pemotongan menggunakan alat potong seperti circular saw dan scroll saw, pada proses pemotongan terdapat beberapa kendala yang sering operator alami diantaranya mata potong sulit dicari, harga satuan mata potong mahal, mata potong sering patah, kekuatan dinamo dapat turun drastis, pekerjaan memerlukan waktu yang lama serta kelelahan yang dirasakan operator sehingga membutuhkan perancanagan untuk mesin potong akrilik yang dapat memenuhi kebutuhan operator dalam bekerja. Metode yang digunakan dalam perancangan menggunakan metode Ergonomic Function Deployment (EFD) yang merupakan perkembangan dari metode Quality Function Deployment (QFD). Tahapan pada penelitian ini, dilakukan studi pendahuluan, identifikasi, perumusan, penetapan tujuan, implementasi metode dilanjut dengan analisa dan pembahasan, ditutup dengan kesimpulan, saran, dan selesai. Berdasarkan hasil penelitian yang telah dilakukan didapatkan hasil variable. Hasil pengolahan Software SPSS 16, diperoleh dari kuesioner tertutup.
\end{abstract}

Kata Kunci : Alat Potong Akrilik, Perancangan, Ergonomic Function Deployment

\section{Pendahuluan}

Periklanan modern di Indonesia diperkirakan dimulai pada abad 20 awal [3]. Iklan telah dimulai pada masa penjajahan Belanda di mana pada masa itu telah ada iklan untuk memperkenalkan barang-barang import orang Belanda di daerah jajahannya [5], Selanjutya iklan mulai berkembang pesat di Indonesia pada masa kemerdekaan dan pembangunan. Hingga kini jasa periklanan berkembang untuk berbagai kepentingan seperti riset pasar, kampanye relasi 
publik, promosi dan lain sebagainya, Hal ini tidak terlepas dari peran iklan yang berfungsi untuk menari perhatian konsumen [7]. Jasa pembuatan iklan ini membantu para pengusaha di Kota Pekanbaru untuk mernprornosikan barang dan jasa yang mereka jual, Dalam proses pengerjaan media iklan sendiri, dibutuhkan satu atau dua orang pekerja dibagian pemotongan, Dalam proses pemotongan terdapat beberapa kendala yang sering operator alami.

Kendala tersebut yakni pada proses mesin berjalan, yang mengalami penurunan tenaga yang diakibatkan dari dinarno, 'Alko Sugianto, 2020" Berikut salah satu mesin yang digunakan operator pemotongan akrilik yang berlokasi di jalan Kereta Api, dengan papan nama Aiko Advertising yang digunakan disalah satu jasa pembuatan media iklan. Mesin dibawah ini adalah mesin potong akrilik jenis scroll saw yang digunakan sebagai mesin ukir, dapat dilihat sebagai berikut:

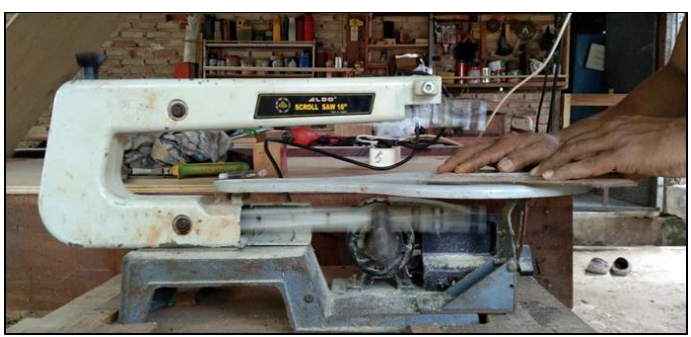

Gambar 1. Mesin Pemotongan Akrilik Scroll Saw

Kendala yang dialami operator selain proses diatas ialah keterbatasan dari meja kerja, kendala lain meja yang tidak sesuai standar kualifikasi yang dibutuhkan. Pemilik dari periklanan Aiko Advertising mengatakan, "meja yang digunakan dalam pemotongan scrolf saw saat ini masih dirasa kurang nyaman. Hal itu dikarenakan meja kerja yang digunakan belum ergonomis.

Dibawah ini gambar operator mesin potong akrilik saat proses pengerjaan periklanan yang dilakukan di Aiko Advertising dengan meja kerja seperti pada gambar, sebagai berikut:

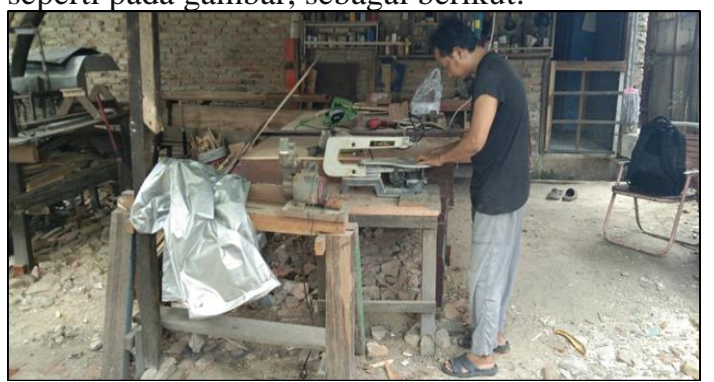

Gambar 2. Operator Mesin Pemotongan Akrilik Mesin Scroll Saw
Berdasarkan penelitian pendahuluan yang telah dilakukan diketahui bahwa mesin yang digunakan selama ini masih memiliki beberapa kekurangan seperti yang dapat dilihat pada tabel dibawah ini

Tabel 1. Rekapitualsi Hasil Kuesioner dengan Pengguna Mesin Potong Akrilik

\begin{tabular}{|c|l|}
\hline No. & \multicolumn{1}{|c|}{ Kendala yang dialami Pengguna Mesin Potong Akrilik } \\
\hline 1 & Mata potong sulit dicari \\
\hline 2 & Mata potong sering patah \\
\hline 3 & Kekuatan dinamo dapat turun drastis \\
\hline 4 & Pekejaan memotong memerlukan waktu yang lama, karena keja mesinlambat \\
\hline 5 & Posisi pengerjaan sering mengalami lelah dibagian kepala \\
\hline 6 & Sering mengalami kelelahan padaleher, dan kepala \\
\hline 7 & Posisi pada punggung menunduk sehingga mengalami rasalelah \\
\hline 8 & Dengan meja yang tidak sesuai ukuran mengalami kram pada otot kaki \\
\hline
\end{tabular}

Berdasarkan hasil observasi, wawancara dan penyebaran kuesioner, mesin yang berada dipasaran yang digunakan dalam melakukan pemotongan bahan akrilik, perlu dilakukan perancangan ulang, sehingga dapat digunakan sesuai kebutuhan. Oleh sebab itu diusulkan "Perancangan Mesin Potong Akrilik Yang Ergonomis Dan Ekonomis Mengggunakan Metode Ergonomic Function Deployment (EFD)"

\section{Kajian Deduktif}

Akrilik

Akrilik adalah nama kristal termoplastik yang jernih dengan narna dagang Lucie, Barex dan Plexiglas. Akrilik banyak digunakan sebagai bahanpe lapis untuk bahan keras lain, dan dahulu digunakan untuk gigi palsu dan kacamata. Kemasan pangan yang menggunakan akrilik adalah botol-botol minuman.

Pemanfaatan limbah akrilik ini diharapkan mampu memberikan nilai jual produk. Sifatnya yang tahan pecah juga menjadikan akrilik sebagai material yang ideal untuk dipergunakan pada aplikasi di tempat-ternpat di mana pecahnya material akan berakibat fatal, seperti salah satunya pada jendela kapal selam. Selain anti pecah dan tahan terhadap cuaca, akrilik juga tidak akan mengkerut atau berubah warna meskipun terkena paparan sinar matahari dalam jangka waktu yang lama. Hal ini membuat semua produk dari bahan akrilik bisa digunakan di dalam atau di luar mangan.

\section{Ergonomi}

Istilah ergonomi berasal dari bahasa Yunani yang terdiri dua kata yaitu "ergon" berarti kerja dan "nomos" berarti aturan atau hukum. Jadi secara ringkas ergonomi adalah suatu aturan atau 
norma dalam sistem kerja. Di Indonesia memakai istilah ergonomi, tetapi di beberapa negara seperti di Skandinavia menggunakan istilah "Bioteknologi" sedangkan di negara Amerika menggunakan istilah "Human Engineering" atau "Human Factors Engineering". Namun demikian, kesemuanya membahas hal yang sama yaitu tentang optimalisasi fungsi manusia terhadap aktivitas yang dilakukan [20].

Secara umum tujuan dari penerapan ergonomi adalah :

1. Meningkatkan kesejahteraan fisik dan mental melalui upaya pencegahan cedera dan penyakit akibat kerja, menurunkan beban kerja fisik dan mental, mengupayakan promosi dan kepuasan kerja.

2. Meningkatkan kesejahteraan sosial melalui peningkatan kualitas kontak sosial, mengelola dan mengkoordinir kerja secara tepat guna dan meningkatkan jaminan sosial baik selama kurun waktu usia produktif maupun setelah tidak produktif

3. Menciptakan keseimbangan rasional antara berbagai aspek yaitu aspek teknis, ekonomis, antropologis dan budaya dari setiap sistem kerja yang dilakukan sehingga tercipta kualitas kerja dan kualitas hidup yang tinggi.

Ergonomic Function Deployment (EFD)

Ergonomic Function Deployment (EFD) merupakan pengembangan dari Quality Function Deployment (QFD) yaitu dengan menambahkan hubungan baru antara keinginan konsumen dan aspek ergonomi dari produk. Hubungan ini akan melengkapi bentuk matrik house of quality yang juga menterjemahkan ke dalam aspek-aspek ergonomi yang diinginkan.

Ergonomic Function Deployment (EFD) adalah metode untuk memudahkan selama proses perancangan, pembuatan keputusan direkam dalam bentuk matriksmatriks sehingga dapat diperiksa ullang serta dimodifikasi di masa yang akan datang, biasanya untuk mengetahui ergonomis atau tidaknya hasil suatu rancangan. Matrik House of Quality yang digunakan pada Ergonomic Function Deployment (EFD) dikembangkan menjadi matrik House of Ergonomic (HOE).

Harga Pokok Produksi

Harga pokok produksi yaitu biaya barang yang telah diselesaikan selama satu periode. Sistem harga pokok produksi yang digunakan perusahaan akan menentukan karakteristik manajemen perusahaan, namun pada dasarnya bertujuan sebagai dasar pengendalian biaya produksi [22].

Penentuan Harga Jual

Harga jual adalah sejumlah uang yang dibebankan atas suatu produk atau jasa, dari nilai yang ditukar konsumen atas manfaat - manfaat karena memiliki atau menggunakan produk atau jasa tersebut [6].

\section{Teknik Sampling}

Teknik sampling adalah cara untuk menentukan sampel yang jumlahnya sesuai dengan ukuran sampel yang akan dijadikan sumber data sebenarnya, dengan memperhatikan sifat-sifat dan penyebaran populasi agar diperoleh sampel yang representative [8]. Untuk menentukan sampel yang akan digunakan dalam penelitian terdapat berbagai teknik sampling yang digunakan. secara skematis [15].

Uji Validitas

Validitas berasal dari kata validity yang mempunyai arti sejauh mana ketepatan dan kecermatan suatu alat ukur dalam melakukam fungsi ukurannya [2]. Selain itu validitas adalah suatu ukuran yang menunjukkan bahwa variabel yang diukur memang benar-benar variabel yang hendak diteliti oleh peneliti.

Uji Realibilitas

Suatu alat disebut reliabel apabila dalam beberapa kali pelaksanaan pengukuran terhadap kelompok subjek sama sekali diperoleh hasil yang relatif sama, selama aspek yang diukur dalam diri subjek memang belum berubah. Dalam hal ini relatif sama berarti tetap ada toleransi perbedaan-perbedaan kecil diantara hasil beberapa kali pengukuran.

\section{Metodologi}

Flowchart Penelitian 


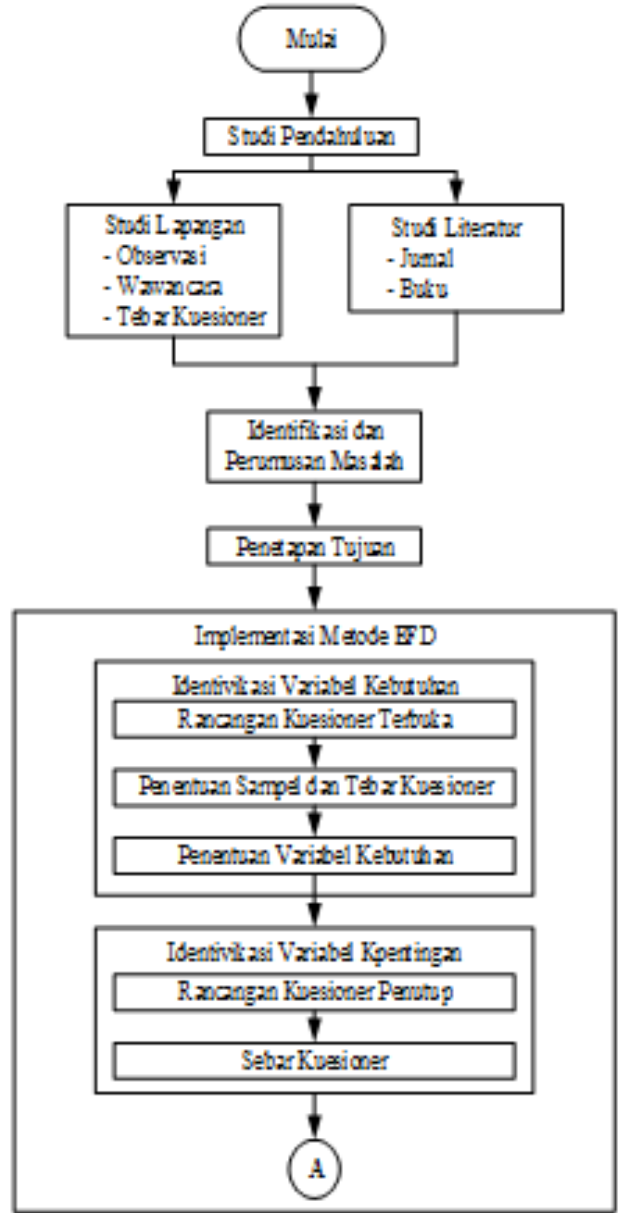

Gambar 3. Flowchart Penelitian

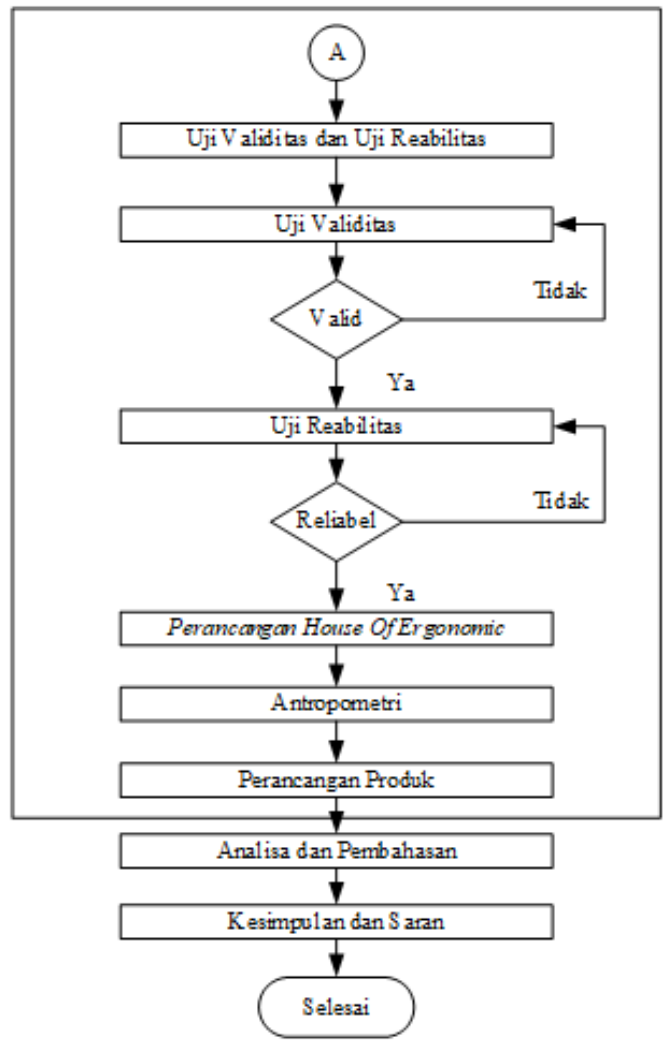

Gambar 4. Flowchart Penelitian (lanjutan)

Studi Pendahuluan

Studi pendahuluan terdiri dari studi lapangan dan studi literatur. Studi lapangan dilakukan melalui observasi secara langsung pada usaha jasa pembuatan akrilik di Alko Advertising, kemudian dilakukan wawancara langsung serta tebar kuesioner terbuka. Sedangkan studi literatur yaitu untuk mencari referensi dalam menganalisa permasalahan yang timbul dan sebagai panduan untuk mendapatkan solusi dari penelitian yang akan dilakukan, studi literatur dapat bersumber dari jurnal ataupun dari buku yang berkaitan dengan masalah terkait mesin potong akrilik dan metode ergonomic function deployment (EFD).

Identifikasi dan Perumusan Masalah

Mengidentifikasi masalah yang terdapat pada perancangan mesin potong akrilik yang ada saat ini. Perumusan masalah adalah suatu tahapan pengerjaan dalam penelitian ini. Masalah yang terdapat pada perancangan mesin potong akrilik pada proses pemotongan ini yaitu pengerjaan yang dilakukan secara manual, yang pada proses pemotongan dengan luas papan meja yang terbatas hanya panjang 16 inci atau $40,64 \mathrm{~cm}$ sehingga output yang dihasilkan sedikit dengan 
waktu yang cukup lama dan dimensi alat terbatas. Sehingga dapat memicu terjadinya kelelahan, hanya dapat menghasilkan potongan bahan akrilik dan dengan keterbatasan fungsi mengakibatkan biaya penggunaan alat lebih besar sehingga menurunkan profit karena dipengaruhi waktu dan keterbatasan area potong.

\section{Penetapan Tujuan}

Penetapan tujuan merupakan target yang ingin dicapai dalam penelitian ini. Tujuan penelitian ini adalah memberikan usulan perancangan mesin akrilik multifungsi yang diinginkan oleh pelaku usaha skala menengah kebawah, memberikan perancangan mesin akrilik yang ergonomi dengan menggunakan metode ergonomic function deployment (EFD).

\section{Implementasi Metode Ergonomic Function Deployment (EFD)}

Identifikasi Variabel Kebutuhan

Identifikasi variabel kebutuhan dari mesin potong akrilik dilakukan melalui beberapa tahapan sebagai berikut:

1. Rancang Kuesioner Terbuka

2. Penentuan Sampel dan Sebar Kuesioner

3. Penentuan Variabel Kebutuhan

Identifikasi Variabel Kepentingan

1. Rancangan Kuesioner Tertutup

2. Sebar Kesioner Tertutup

Uji Validitas dan Reabilitas

Sebelum dilakukan pengolahan data, perlu dilakukan uji statistik yang meliputi uji validitas dan reliabilitas.

1. Uji Validitas

Uji validitas dilakukan untuk mengetahui sejauh mana suatu alat pengukur yaitu kuesioner yang mengukur apa yang ingin diukur. Kriteria validasi suatu pertanyaan dapat ditentukan jika :

a. $\mathrm{r}$ hitung $>\mathrm{r}$ tabel, maka pertanyaan yang diajukan valid.

b. $\mathrm{r}$ hitung $<\mathrm{r}$ tabel, maka pertanyaan yang diajukan tidak valid.

2. Uji Reliabilitas

Kuesioner sebagai alat ukur harus diuji kehandalannya untuk mendapatkan mutu. Dengan kata lain reliabilitas menunjukkan konsistensi suatu alat ukur dalam mengukur gejala yang sama. Tinggi rendahnya nilai reliabilitas ditunjukkan oleh satu angka yang disebut koefisien reliabilitas, yakni sebesar antara 0,00-1,00.
Perancangan House Of Ergonomic

Tahapan ini dilakukan untuk mengetahui hubungan antara setiap kebutuhan konsumen dan kepentingan teknik serta melakukan perangkingan (prioritas) untuk mendapatkan perancangan mesin potong akrilik.

Antropometri

Pada tahap ini dilakukan pengambilan data antropometri operator mesin akrilik yang merupakan penguna dari mesin potong akrilik yang akan dirancang. Dan data antropometri ini diperoleh dari pengguna mesin potong akrilik saat ini sebanyak sampel yang terdata.

Perancangan Produk

Perancangan produk dilakukan setelah diperoleh spesifikasi dari House of Ergonomic (HOE). Rancangan produk disesuaikan dengan ukuran antropometri dan persentil yang digunakan.

Pembahasan

Pada tahap ini dilakukan analisa dan pembahasan berdasarkan hasil pengolahan data Ergonomic Function Deployment (EFD) terhadap rancangan mesin potong akrilik.

Kesimpulan dan Saran

Pada tahap ini, disusun kesimpulan yang akan menjawab tujuan penelitian dan tahap-tahap yang telah dilakukan serta pemberian saran yang mencakup saran dalam implementasi, penelitian lanjutan yang dapat dilakukan, serta kekurangan dalam proses penelitian.

\section{Hasil dan Pembahasan}

Populasi dan Sampel

Identifikasi Rensponden

Tabel 2. Data Identitas Rensponden Berdasarkan Jenis Kelamin

\begin{tabular}{|c|l|c|}
\hline No. & Jenis Kelamin & Jumlah \\
\hline 1 & Pria & 51 \\
\hline 2 & Wanita & 0 \\
\hline \multicolumn{2}{|c|}{ Total } & 51 \\
\hline
\end{tabular}

Tabel 3. Data Identitas Rensonden Berdasarkan

\begin{tabular}{|c|c|c|}
\hline Usia \\
\hline No. & Usia & Jumlah \\
\hline 1 & $17-25$ thn & 27 \\
\hline 2 & $26-34$ thn & 13 \\
\hline 3 & $>35$ thn & 11 \\
\hline
\end{tabular}




\begin{tabular}{|l|l|}
\hline Total & 51 \\
\hline
\end{tabular}

Tabel 4. Data Identitas Rensonden Berdasarkan Pendidikan

\begin{tabular}{|c|l|c|}
\hline No. & \multicolumn{1}{|c|}{ Pendidikan } & Jumlah \\
\hline 1 & SMA/SMK & 20 \\
\hline 2 & Diploma & 0 \\
\hline 3 & Sarjana & 31 \\
\hline \multicolumn{2}{|c|}{ Total } & 51 \\
\hline
\end{tabular}

Tabel 5. Data Identitas Rensonden Berdasarkan Penghasilan

\begin{tabular}{|c|c|c|}
\hline No. & Penghasilan & Jumlah \\
\hline 1 & $1.500 .000-2.500 .000$ & 8 \\
\hline 2 & $2.500 .000-3.500 .000$ & 5 \\
\hline 3 & $3.500 .000-5.000 .000$ & 15 \\
\hline 4 & $>5.000 .000,-$ & 23 \\
\hline \multicolumn{2}{|c|}{ Total } & 51 \\
\hline
\end{tabular}

Tabel 6. Data Identitas Rensonden Berdasarkan Lama Bekerja

Penentuan Variabel Kebutuhan Berdasarkan ENASE (Efektif, Nyaman, Aman, Sehat dan Efesien)

\begin{tabular}{|c|c|c|c|}
\hline Aspek & Kode & $\begin{array}{c}\text { Variabel } \\
\text { Kebutuhan }\end{array}$ & Keterangan \\
\hline Efektif & v1 & $\begin{array}{c}\text { Praktis } \\
\text { Digunakan }\end{array}$ & $\begin{array}{l}\text { Desain mesin potong akrilik dapat } \\
\text { dipahami oleh operator }\end{array}$ \\
\hline Nyaman & v2 & $\begin{array}{c}\text { Nyaman } \\
\text { Digunakan }\end{array}$ & $\begin{array}{l}\text { Dimensi mesin potong akrilik sesuai } \\
\text { dengan ukuran tubuh operator/pengguna } \\
\text { mesin }\end{array}$ \\
\hline Aman & v3 & $\begin{array}{l}\text { Produk Tahan } \\
\text { Lama }\end{array}$ & Mesin potong akrilik kuat dantahanlama \\
\hline Sehat & v4 & Desain Menarik & $\begin{array}{l}\text { Desain mesin potong akrilik menarik dan } \\
\text { aman digunakan }\end{array}$ \\
\hline \multirow{2}{*}{ Efesien } & v5 & $\begin{array}{c}\text { Harga } \\
\text { Terjangkau }\end{array}$ & Mesin potong akrilik harganya tejangkau \\
\hline & v6 & Multifungsi & $\begin{array}{l}\text { Mesin Potong akrilik dapat digunakan lebih } \\
\text { dari satu fungsi }\end{array}$ \\
\hline
\end{tabular}

Pengukuran Tingkat Kepentingan Konsumen (Importance to Custumer)

Tabel 7. Rekap Data Hasil Kepentingan

\begin{tabular}{|c|c|c|c|c|c|c|c|c|c|}
\hline \multirow{2}{*}{ No } & \multirow{2}{*}{$\begin{array}{c}\text { Kode } \\
\text { Variabel }\end{array}$} & \multirow{2}{*}{$\begin{array}{c}\text { Variabel } \\
\text { Kebutuhan }\end{array}$} & \multicolumn{5}{|c|}{ Tingkat Kepentingan } & \multirow{2}{*}{$\sum \mathrm{Ni}$} & \multirow{2}{*}{$\begin{array}{c}\text { Important } \\
\text { to } \\
\text { Customer }\end{array}$} \\
\hline & & & STP & TP & CP & $P$ & SP & & \\
\hline 1 & V1 & $\begin{array}{l}\text { Praktis } \\
\text { digunakan }\end{array}$ & 0 & 0 & 7 & 18 & 26 & 223 & 4.46 \\
\hline 2 & v2 & $\begin{array}{l}\text { Produk } \\
\text { tahan lama }\end{array}$ & 0 & 0 & 1 & 30 & 20 & 223 & 4.46 \\
\hline 3 & v3 & $\begin{array}{l}\text { Desain } \\
\text { Menarik }\end{array}$ & 0 & 6 & 21 & 22 & 2 & 173 & 3.46 \\
\hline 4 & v4 & $\begin{array}{l}\text { Nyaman } \\
\text { Digunakan }\end{array}$ & 0 & 0 & 16 & 23 & 12 & 200 & 4.00 \\
\hline 5 & v5 & Multifungsi & 0 & 0 & 1 & 26 & 24 & 227 & 4.54 \\
\hline 6 & v6 & $\begin{array}{l}\text { Harga } \\
\text { Terjangkau }\end{array}$ & 0 & 0 & 5 & 19 & 27 & 226 & 4.52 \\
\hline
\end{tabular}

Pengukuran Tingkat Kepuasan Konsumen (Current Statifitation Performance)

Tabel 8. Rekap Data Hasil Kepuasan

\begin{tabular}{|c|c|c|c|c|c|c|c|c|c|}
\hline \multirow{2}{*}{ No } & \multirow{2}{*}{$\begin{array}{c}\text { Kode } \\
\text { Variabel }\end{array}$} & \multirow{2}{*}{$\begin{array}{c}\text { Variabel } \\
\text { Kebutuhan }\end{array}$} & \multicolumn{5}{|c|}{ Tingkat Kepentingan } & \multirow{2}{*}{$\sum \mathrm{Ni}$} & \multirow{2}{*}{$\begin{array}{c}\text { Current } \\
\text { Stafication } \\
\text { Performance }\end{array}$} \\
\hline & & & STP & TP & $\mathrm{CP}$ & $P$ & SP & & \\
\hline 1 & V1 & $\begin{array}{l}\text { Praktis } \\
\text { digunakan }\end{array}$ & 7 & 18 & 26 & 0 & 0 & 121 & 2.42 \\
\hline 2 & V2 & $\begin{array}{l}\text { Produk } \\
\text { tahan lama }\end{array}$ & 1 & 30 & 20 & 0 & 0 & 121 & 2.42 \\
\hline 3 & V3 & $\begin{array}{l}\text { Desain } \\
\text { Menarik }\end{array}$ & 21 & 22 & 2 & 0 & 0 & 71 & 1.42 \\
\hline 4 & V4 & $\begin{array}{l}\text { Nyaman } \\
\text { Digunakan }\end{array}$ & 16 & 23 & 12 & 0 & 0 & 98 & 1.96 \\
\hline 5 & V5 & Multifungsi & 1 & 26 & 24 & 0 & 0 & 125 & 2.50 \\
\hline 6 & V6 & $\begin{array}{l}\text { Harga } \\
\text { Terjangkau }\end{array}$ & 5 & 19 & 27 & 0 & 0 & 124 & 2.48 \\
\hline
\end{tabular}

Penentuan Nilai Target (Goal)

Tabel 9. Goal (Target)

\begin{tabular}{|c|c|l|c|}
\hline No & $\begin{array}{c}\text { Kode } \\
\text { Variabel }\end{array}$ & $\begin{array}{c}\text { Variabel } \\
\text { Kebutuhan }\end{array}$ & Goal \\
\hline 1 & V1 & Praktis digunakan & 3 \\
\hline 2 & V2 & Produk tahanlama & 4 \\
\hline 3 & V3 & Desain Menarik & 4 \\
\hline 4 & V4 & $\begin{array}{l}\text { Nyaman } \\
\text { Digunakan }\end{array}$ & 4 \\
\hline 5 & V5 & Multifungsi & 3 \\
\hline 6 & V6 & Harga Terjangkau & 4 \\
\hline
\end{tabular}

Penentuan Technical Responses

Tabel 10. Technical Responses 


\begin{tabular}{|c|c|l|c|}
\hline No & $\begin{array}{c}\text { Kode } \\
\text { Variabel }\end{array}$ & $\begin{array}{c}\text { Variabel } \\
\text { Kebutuhan }\end{array}$ & Respon Teknis \\
\hline 1 & V1 & Praktis digunakan & Desain Produk \\
\hline 2 & V2 & $\begin{array}{l}\text { Produk tahan } \\
\text { lama }\end{array}$ & $\begin{array}{c}\text { Material } \\
\text { berkualitas }\end{array}$ \\
\hline 3 & V3 & Desain Menarik & Desain Produk \\
\hline 4 & V4 & $\begin{array}{l}\text { Nyaman } \\
\text { Digunakan }\end{array}$ & Dimensi Produk \\
\hline 5 & V5 & Multifungsi & Desain Produk \\
\hline 6 & V6 & $\begin{array}{l}\text { Harga } \\
\text { Terjangkau }\end{array}$ & $\begin{array}{c}\text { Material } \\
\text { berkualitas }\end{array}$ \\
\hline
\end{tabular}

Komponen Material Produk

Tabel 11. Spesifikasi Pemilihan Material Produk

\begin{tabular}{|c|c|c|c|}
\hline \multirow{4}{*}{ No. } & Bagian & Bahan & Spesifikasi \\
\hline \multirow{4}{*}{1} & \multirow{4}{*}{$\begin{array}{c}\text { Kerangka } \\
\text { Utama }\end{array}$} & Besi Hollow & Kuat, Ringan, Tahan Getaran \\
\cline { 3 - 4 } & & Triplek & Kuat, Ringan \\
\cline { 3 - 4 } & Besi Siku & Kuat, Tahan Lama \\
\cline { 3 - 4 } 2 & Plat Besi & Kuat, Tahan Lama \\
\hline \multirow{4}{*}{$\begin{array}{c}\text { Sistem } \\
\text { Penggerak }\end{array}$} & Dinamo Penggerak & Putaran Kuat, Tahan Lama \\
\cline { 3 - 4 } & & Pulley Sambungan & Kuat, Ringan, Tahan Lama \\
\cline { 3 - 4 } & & Pulley Biasa & Kuat, Ringan, Tahan Lama \\
\cline { 3 - 4 } & & Bearing & Kuat, Tahan Lama \\
\cline { 3 - 4 } & & Tuas Penggerak & Elastis, Ringan \\
\cline { 3 - 4 } & & Kuat, Tahan Lama \\
\hline \multirow{3}{*}{3} & $\begin{array}{c}\text { Mata } \\
\text { Potong }\end{array}$ & Circular Saw & Kuat, Tahan Lama \\
\cline { 3 - 4 } & Scroll Saw & Kuat, Tahan Lama \\
\hline
\end{tabular}

Gambar Rancangan Alat Potong Akrilik

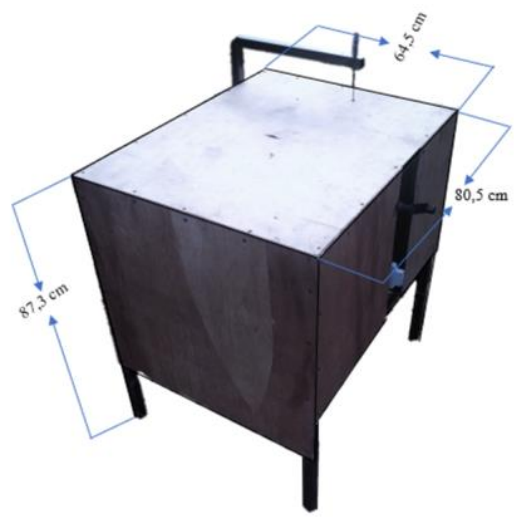

Gambar 5. Rancangan Alat Porong Akrilik

\section{Simpulan}

Adapun kesimpulan dari penelitian Perancangan Alat Pemotong Akrilik Multifungsi yang Ergonomis dan Ekonomis Menggunakan Metode Ergonomic Function Deployment (EFD).

Spesifikasi alat pemotong akrilik yang dibutuhkan berdasarkan hasil variabel kebutuhan diantaranya praktis digunakan, produk tahan lama, desain menarik, nyaman digunakan, multifungsi, harga dan harga terjangkau dengan respon teknis desain produk, dimensi produk dan material berkualitas

3. Hasil produk multi fungsi yang ergonomis dapat dilihat pada gamber sebagai berikut:

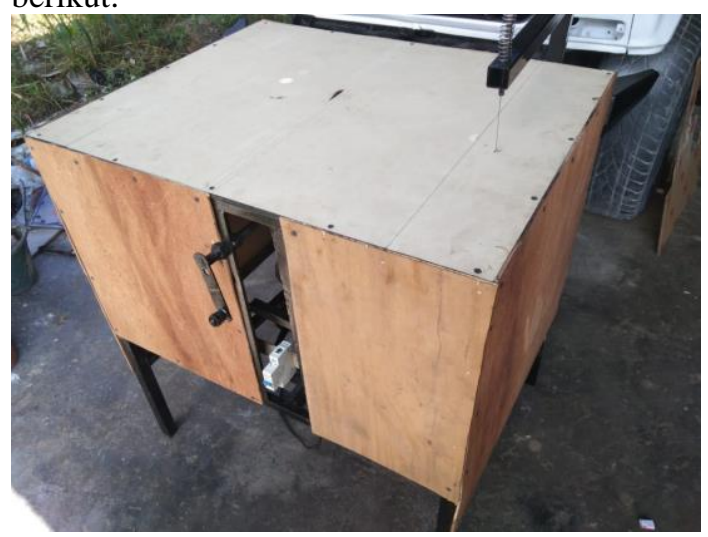

Gambar 6. Alat Mesin Potong Akrilik Multifungsi

Saran

Berdasarkan hasil yang dirancang didapat adapun hal yang menjadi saran sebgai berikut:

1. Perancangan selanjutnya diharapkan lingkupannya untuk usaha yang berskala menengah keatas

2. Desain rancangan selanjutnya diharapkan untuk lebih banyak fungsinya.

3. Kebisingan alat selanjutnya diteliti kembali dan getaran pada alat itu juga.

4. Diperhatikan aspek ergonominya kembali.

Daftar Pustaka

[1]. Andriani, Puspita Debrina dkk. 2017. Aplikasi Quality Function Deployment Untuk Redesign Kontainer Penyimpanan Pada Industri Kemasan Kaleng. Fakultas Teknik. Universitas Brawijaya.

[2]. Azwar, S.1986. Reliabilitas dan Validitas Interprestasi dan Komputasi. Liberty. Yogyakarta.

[3]. Belch, George E \& Michael A. 1998. Advertising and Promotion, Mc Graw Hill Companies, Inc., Boston, Massachusetts.

[4]. Claudia, Reny Karina. dan Setiawan, Andereas Pandu. 2017. Perancangan Kap Lampu Hias dengan Material Tembus Cahay. Jurnal Intra Vol. 5, No. 2. 798-801. Program Studi Desain Interior, Universitas Kristen Petra.

[5]. Collier, John. 1992. Visual Anthropology, University of New Mexico Press, Alburquerque. 
[6]. Kotler, Philip and Kevin Lane Keller. (2016). Marketing Management 15e. New Jersey: Person Prentice Hall, Inc.

[7]. Krugman, D. M, dkk. 1994. Advertising, The Dryden Press, Sydney.

[8]. Margono. 2004. "Teknik Pengambilan Sampel Sampling”. Pada hari jumat 1 Juni 2018 pukul 14:18 WIB

[9]. Mulyadi. 2009. Akutansi Biaya. Edisi ke 5. Yogyakarta : STIE YKPN

[10]. Mohd. Syaryadhi, 2007. Sistem Berat Menggunakan Sensor Load Cell, Jurnal Rekayasa Elektrika. Vol. 6, no. 1.

[11]. Novianto, Tri dkk. 2017. Perancangan Dan Pengembangan Desain Produk Meja Warung/Café Lesehan Multifungsi Yang Ergonomis Menggunakan Metode Ergonomic Function Deployment (EFD). Fakultas Teknik Industri Universitas Dian Nuswantoro Semarang.

[12]. Paryanto, 2015. Proses Gerinda. Fakultas Teknik Mesin. Universitas Negeri Yogyakarta

[13]. Pugersari, Dewi, dkk. 2013 . Eksperimen Pengembangan Produk Fungsional Bernilai Komersial Berbahan Baku Tempurung Kelapa Berusia Muda dengan Teknik Pelunakan. ITB Journal of Visual Art and Design, Vol. 5, no. 1. Institut Teknologi Bandung, Indonesia.

[14]. Reniati. 2013. Kreatifitas Organisasi dan Inovasi Bisnis. Alfabeta. Bandung

[15]. Sugiyono. 2010. Metode Penelitian Kuantitif, Kualitatif dan R\&D. Bandung: Alfabeta.

[16]. Sujarweni, V. Wiratna. 2017. Analisis Laporan Keuangan : Teori, Aplikasi, \& Hasil Penelitian. Yogyakarta: Pustaka Baru Press.

[17]. Sutalaksana, Z Iftikar. 1997. Teknik Tata Cara Kerja. Institut Teknologi Bandung. Bandung.

[18]. Sukarno Gendut. 2016. Knowledge Broker Sebagai Pemoderasi Hubungan Di Antara Knowledge Management Dan Intellectual Capital Serta Dampaknya Terhadap Kinerja Industri Kreatif Di Jawa Timur. Diakses: 06/07/2018.

[19]. Tarwaka, Sholichul, Lilik Sudiajeng, 2004. Ergonomi Untuk Keselamatan, Kesehatan Kerja dan Produktivitas. Surakarta. UNIBA PRESS

[20]. Tarwaka. 2015. Ergonomi Industri, Dasar-Dasar Pengetahuan Ergonomi dan
Aplikasi di Tempat Kerja. Solo: Harapan Press Solo.

[21]. Wahmuda, Faza dan Puspitasari, Ratna. 2015. Pengembangan Desain Produk dari Tongkol Jagung berbasis Industri Kreatif. Prosiding Seminar Nasional Sains dan Teknologi Terapan "SNTEKPAN III" 2015. 13 Oktober 2015. Institut Teknologi Adhi Tama Surabaya.

[22]. Wiwin dan Ilham Wahyudi. 2008. Pengantar Akuntansi. Jakarta : Prenada Media Group. 